\title{
Heavy Metal Concentrations with Regard to Inter-Species Variation in Cattle and Buffalo Milk Collected from Different Areas of North Gujarat
}

\author{
Rashmika R. Desai, Hitesh B. Patel, Ratn Deep Singh*', Vaidehi N. Sarvaiya, \\ Mahesh M. Pawar and Shailesh K. Mody \\ Department of Pharmacology and Toxicology, College of Veterinary Science \& A. H., \\ Sardarkrushinagar Dantiwada Agricultural University, \\ Sardarkrushinagar-385506, Banaskantha, India
}

*Corresponding author

\section{A B S T R A C T}

\begin{tabular}{|l|}
\hline K e y w o r d s \\
$\begin{array}{l}\text { Heavy metals, Inter- } \\
\text { species variation, Cattle, } \\
\text { Buffalo, North Gujarat, } \\
\text { Atomic absorption } \\
\text { spectrophotometer }\end{array}$ \\
\hline Article Info \\
\hline $\begin{array}{l}\text { Accepted: } \\
\text { 12 July } 2018 \\
\text { Available Online: } \\
\text { 10 August } 2018\end{array}$ \\
\hline
\end{tabular}

\section{Introduction}

Food safety and traceability control in the production of dairy animal products has become crucial criteria for the consumers because of the novel requirements of food for disease prevention and health (Poti et al., 2012). Contamination of environment with heavy metals leads to the presence of such toxic compounds in the food of animal origin in varying degree. Heavy metals often termed as 'toxic metals' are important environmental contaminant leading to their appearance in milk. This may be through natural or

\begin{abstract}
In the present study, heavy metal residual concentrations of cadmium $(\mathrm{Cd})$, lead $(\mathrm{Pb})$ and copper $(\mathrm{Cu})$ in cattle and buffalo milk samples collected from three districts of the Northern part of Gujarat state were determined. A total of 800 samples were collected during the entire study in summer and winter seasons. Heavy metal $(\mathrm{Cd}, \mathrm{Pb}$ and $\mathrm{Cu})$ residues in milk samples were determined by the Atomic Absorption Spectrometry (AAS) technique. The average values of $\mathrm{Cd}, \mathrm{Pb}$ and $\mathrm{Cu}$ in the milk of cattle were found to be $0.033 \pm 0.002,0.121 \pm 0.014$ and $0.097 \pm 0.012 \mathrm{mg} / \mathrm{L}$, respectively. Similar values for buffalo milk were $0.030 \pm 0.002,0.139 \pm 0.015$ and $0.168 \pm 0.036 \mathrm{mg} / \mathrm{L}$, respectively. The inter-species comparison between cattle and buffalo demonstrated the higher level of $\mathrm{Cd}$, $\mathrm{Pb}$ and $\mathrm{Cu}$ in buffalo milk. There was non-significant difference in the level of heavy metals in the milk of cattle and buffalo.
\end{abstract}

anthropogenic sources. The risk involved is due to their persistence, toxicity and ability to be accumulated into the environment and subsequently into the food chain.

Heavy metals are bio-transferred, bioaccumulated and biomagnified in food chain and food webs. Animals like cattle, buffalo, sheep and goat feed on grasses and plants which may contain pollutants like heavy metals, so that heavy metals are biotransferred in their bodies and these heavy metals either harm or accumulate in their bodies (Nazir et al., 2015). 
The level of heavy metals in the milk of dairy animals directly indicates food safety and hygienic status of food for consumers. It also indirectly reflects degree of environmental contamination where milk is either produced or procured (Licata et al., 2004 and GonzalezMontana et al., 2012).

Contamination of milk by toxic metals can be a possible health risk to human population (Caggiano et al., 2005). Pollution of the environment with metals such as lead is a world-wide problem. Lead and cadmium residues in milk are of particular concern because milk is largely consumed by infants and children (Zheng et al., 2007). Lead is well absorbed from milk (Morisson and Quarterman, 1987). Lead is a non-essential element and causes fatal type of disease such as Alzheimer's disease, renal, reproductive, endocrine, nervous disorders and decreases intelligence quotient (IQ) level of children (Ahmad et al., 2011). Cadmium extremely irritates stomach leading to antiperistalsis, vomition, and diarrhoea and may cause death (Bushra et al., 2014). Cadmium is also implicated in high blood pressure, prostate cancer, mutations and fetal death (Pitot and Dragan, 1996). Copper plays a very significant role in growth while overexposure of copper can cause hepatic copper II overload disease, tissue injury, irritation of lungs and hepatic cancer (Bushra et al., 2014).

The northern region of Gujarat state contributes more than $50 \%$ share of total milk production of Gujarat. The three districts included in the present study are Banaskantha, Mehsana, Gandhinagar, which contribute nearly $13.19,7.03$ and $3.27 \%$ share of total milk production of North Gujarat, respectively. The dairying and animal husbandry are major tools for livelihood and food security. The quality and safe milk production are the backbone of dairy industry for domestic as well as foreign export. Hence the present investigation on monitoring of heavy metals in milk of cattle and buffalo in North Gujarat was planned with objectives to generate data relevant to heavy metals $(\mathrm{Cd}, \mathrm{Pb}$ and $\mathrm{Cu}$ ) in cattle and buffalo milk over different areas of North Gujarat and to determine if any inter-species variation exists in this regard.

\section{Materials and Methods}

\section{Reagents}

The trichloroacetic acid and nitric acid (SDFL, India, Extra pure grade) were procured and used for the analysis of heavy metals. The deionized water was prepared using Ultra Water Purifier (SG, Germany). All glassware was thoroughly cleaned with a detergent solution, rinsed with metal free water and soaked overnight or longer in a covered acid bath containing $6 \% \mathrm{HNO}_{3}$ solution.

\section{Collection of samples}

Milk samples from cattle and buffalo were collected from different regions of North Gujarat having distinct climatic and geographic characteristics. Three different districts i.e. Gandhinagar, Mehsana and Banaskantha were chosen for sample collection. The five villages were selected within each designated area of sample collection.

The total number of samples collected for the entire experiment was 800 . The area-wise and species-wise details of sample collection are shown in Table 1. The samples were collected during morning milking hour directly by milking of animals at the collection point/ farmers' door-step. About $10 \mathrm{ml}$ of milk was collected in a clean and dry centrifuge tube. The samples were placed immediately in an ice jacket box packed with an ice pack and ice cubes. On reaching the laboratory (same day), 
the samples were transferred to deep freeze at $-20^{\circ} \mathrm{C}$ until analyzed by AAS.

\section{Standard preparation in AAS analysis}

The standards of each element were procured from ECIL, India and used for the AAS analysis. The stock solution of $100 \mathrm{mg} / \mathrm{L}$ was prepared and used to prepare working standards of $0.1,0.2,0.4,0.8,1.0$ and 10.00 $\mathrm{mg} / \mathrm{L}$ using $6 \% \mathrm{HNO}_{3}$. The calibration curve was prepared by plotting known concentration versus absorbance values and used to estimate the concentration of toxic metals from unknown samples.

\section{Sample digestion}

Five $\mathrm{ml}$ of milk sample was measured in a beaker and topped to $5 \mathrm{ml}$ with distilled water (this was done to dilute the milk since it was too thick for analysis in its undiluted form). Exact $5 \mathrm{ml}$ of $0.1 \mathrm{M}$ trichloroacetic acid was added to the sample to precipitate the proteins in the milk. The samples were then centrifuged at a speed of 4000 RPM for 20 minutes. The aqueous fraction was then separated by decanting and poured into the porcelain crucibles having a mark for easy identification. Crucible content was ashed in a muffle furnace for three hours at $500{ }^{\circ} \mathrm{C}$. The ash was then dissolved and reconstituted in 15 $\mathrm{ml}$ of $6 \%$ nitric acid solution. The dissolved sample was then filtered with filter paper (Whatman Paper No. 41). It was then poured into dry and clean centrifuge tubes (Prior washed with de-ionized water) for temporary storage until assay was done. The final makeup of $15 \mathrm{ml}$ was done for each sample before analysis (Patel et al., 2017).

\section{Analytical procedure for AAS}

Heavy metal $(\mathrm{Cd}, \mathrm{Pb}$ and $\mathrm{Cu})$ residues in milk were determined by the AAS (Atomic Absorption Spectrometry). Atomic Absorption
Spectrophotometer (ECIL, Electronics Corporation of India Limited, Model AAS4141) equipped with hydride generator was used for determination of heavy metals. The hollow-cathode lamps for $\mathrm{Cd}, \mathrm{Pb}$ and $\mathrm{Cu}$ (Photron) were employed as the radiation source. The fuel used was a mixture of air and acetylene. Digested samples were analyzed using flame atomic absorption spectrophotometer. Standard dilutions for each metal were prepared in five different concentrations from their respective stock solution $(100 \mathrm{mg} / \mathrm{L})$ to obtain a calibration curve. All the measurements were run in triplicate for the samples and standard solutions. The instrumental conditions during the analysis are listed in Table 2.

\section{Quality assurance}

Appropriate quality assurance procedures were taken to ensure the reliability of the results. In addition, samples were carefully handled to avoid contamination. Moreover, the glassware was properly cleaned and reagents used were of analytical grades. The de-ionized water was used throughout the study. Each time standards were run before the sample run in the AAS.

\section{Statistical analysis}

The significance of the result difference between cattle and buffalo were tested using student's ' $t$ ' test. The impacts of species variation on the concentration of heavy metal in milk were tested using SPSS 16.0 for Windows $^{\circledR}$ and GraphPad PRISM ${ }^{\circledR}$ (version 7.00).

\section{Results and Discussion}

Interspecies comparison of mean $\pm \mathrm{SE}$ values of $\mathrm{Cd}, \mathrm{Pb}$ and $\mathrm{Cu}(\mathrm{mg} / \mathrm{L})$ in cattle and buffalo milk collected from all four areas is summarized in Table 3. There was non- 
significant difference in the average concentrations of $\mathrm{Cd}, \mathrm{Pb}$ and $\mathrm{Cu}$ in cattle and buffalo milk. Interspecies comparison of a range of $\mathrm{Cd}, \mathrm{Pb}$ and $\mathrm{Cu}(\mathrm{mg} / \mathrm{L})$ in cattle and buffalo milk collected from all four areas is presented in Table 4. The interspecies differences were evident in minimum and maximum values of all respective metals between cattle and buffalo milk collected from all four areas. The highest concentration of $\mathrm{Cu}$ in buffalo $(8.959 \mathrm{mg} / \mathrm{L})$ and cattle milk $(2.370$ $\mathrm{mg} / \mathrm{L})$ were observed.

Summary of interspecies comparison of cattle and buffalo milk samples with respect to presence of heavy metals and comparison with MRLs of respective metals are presented in Table 5. The results of the study were direct indicator of food safety and quality of milk. No samples of cow and buffalo milk were found to contain heavy metals $(\mathrm{Cd}, \mathrm{Pb}$ and $\mathrm{Cu}$ ) above MRLs.

The quality of milk needs special attention to make it acceptable widely without imposing any risk on consumers' health. Once heavy metals get absorbed, accumulate in the body, even for the whole span of life (Bernard, 2008). Even at low concentrations, certain heavy metal can adversely affect a number of metabolic processes in the animal body.

Being hazardous and toxic, the presence of heavy metals in the foods of livestock origin especially dairy milk needs to be evaluated and its safety must be established with respect to quality and quantity of metal contaminants. Further, such study indirectly reflects the levels of contamination and pollution of environmental resources as well as their link to the health status of dairy animals. Looking at all these important aspects, the present study to monitor the levels of heavy metals and to study inter-species variation in the milk of cattle and buffalo of North Gujarat were planned and executed.
The inter-species variation, when compared, higher levels $(\mathrm{mg} / \mathrm{L})$ of $\mathrm{Cd}(0.030 \pm 0.002), \mathrm{Pb}$ $(0.139 \pm 0.015)$ and $\mathrm{Cu}(0.168 \pm 0.036)$ in buffalo milk were observed than their respective values, $\mathrm{Cd}(0.033 \pm 0.002), \mathrm{Pb}$ $(0.121 \pm 0.014)$ and $\mathrm{Cu}(0.097 \pm 0.012)$ in cattle milk in present investigation. This might be due to non-selective grazing habit of buffalo species and can graze at any contaminated vegetation. While cattle being highly selective in grazing habits, is likely to avoid the grazing or feeding on contaminated food sources. The interspecies variation in the level of heavy metals might be due to variation in feeding/ grazing habits, disposition characteristics of particular species with respect to toxic metals and intensity of exposure in terms of duration and amount. Contradictory results were reported by Birghila et al., (2008) for $\mathrm{Cd}, \mathrm{Pb}$ and $\mathrm{Cu}$ in cow milk in Romania; Qin et al., (2009) for $\mathrm{Cd}$ in cattle milk in China and Japan; Aslam et al., (2011) for $\mathrm{Cd}$ and $\mathrm{Pb}$ in cow milk in Pakistan and Abdulkhaliq et al., (2012) for $\mathrm{Cu}$ and $\mathrm{Pb}$ in cattle milk in Palestine, as compared to findings of present study. Furthermore, lower concentrations of $\mathrm{Cd}$ and $\mathrm{Pb}$ in cattle milk (Tona et al., 2013) were also reported in Nigeria.

The variations in the concentration of heavy metals observed in present study in comparison to other reported studies might be due to the difference in levels of exposure, intensity of contamination of natural resources and feeding/grazing patterns over study areas involved in other reports.

The average concentration of lead in present study ranged from 0.001 to $2.019 \mathrm{mg} / \mathrm{L}$ in cattle milk and 0.001 to $2.442 \mathrm{mg} / \mathrm{L}$ in buffalo milk with a mean value of 0.121 and 0.139 $\mathrm{mg} / \mathrm{L}$, respectively. Extremely higher average value of $\mathrm{Pb}$ concentration in cattle milk $(18.870 \mathrm{mg} / \mathrm{L})$ was observed in Faislabad area of Pakistan (Javed et al., 2009). 
Table.1 Species and area wise details of sample collection

\begin{tabular}{|c|c|c|c|c|}
\hline Sr. & \multirow{2}{*}{ District } & \multicolumn{2}{|c|}{ Species } & Total no. of samples \\
No. & & Cattle & Buffalo & 400 \\
\hline 1 & Mehsana & 116 & 284 & 200 \\
\hline $\mathbf{2}$ & Gandhinagar & 135 & 65 & 200 \\
\hline $\mathbf{3}$ & Banaskantha & 59 & 141 & 800 \\
\hline
\end{tabular}

Table.2 Instrumental condition for analysis

\begin{tabular}{|c|c|c|c|c|}
\hline Sr. No. & Parameters & Cd & $\mathbf{P b}$ & $\mathrm{Cu}$ \\
\hline 1 & Wavelength (nm) & 228.8 & 217 & 324.8 \\
\hline 2 & Slit width (nm) & 0.5 & 1.0 & 0.5 \\
\hline 3 & Light source & \multicolumn{3}{|c|}{ HCL-Hollow Cathode Lamp } \\
\hline 4 & Flame type & \multicolumn{3}{|c|}{$\mathrm{Air} / \mathrm{C}_{2} \mathrm{H}_{2}$} \\
\hline 5 & Current(ma) & 3.5 & 10 & 5 \\
\hline 6 & AAS Technique & \multicolumn{3}{|c|}{ Flame } \\
\hline
\end{tabular}

Table.3 Interspecies comparison of mean $\pm \mathrm{SE}$ values of $\mathrm{Cd}, \mathrm{Pb}$ and $\mathrm{Cu}(\mathrm{mg} / \mathrm{L})$ in cattle and buffalo milk collected from all four areas

\begin{tabular}{|c|c|c|}
\hline Residue & Cattle & Bufialo \\
\hline $\mathbf{C d}$ & $0.033 \pm 0.002$ & $0.030 \pm 0.002$ \\
\hline $\mathbf{P b}$ & $0.121 \pm 0.014$ & $0.139 \pm 0.015$ \\
\hline $\mathbf{C u}$ & $0.097 \pm 0.012$ & $0.168 \pm 0.036$ \\
\hline
\end{tabular}

$*$ = Significantly $(\mathrm{p} \leq 0.05)$ different from their respective values

Table.4 Interspecies comparison of range of $\mathrm{Cd}, \mathrm{Pb}$ and $\mathrm{Cu}(\mathrm{mg} / \mathrm{L})$ in cattle and buffalo milk collected from all four areas

\begin{tabular}{|c|c|c|}
\hline Residue & Cattle (Range) & Buffalo(Range) \\
\hline $\mathbf{C d}$ & $0.001-0.080$ & $0.001-0.088$ \\
\hline $\mathbf{P b}$ & $0.001-2.019$ & $0.001-2.442$ \\
\hline $\mathbf{C u}$ & $0.001-2.370$ & $0.001-8.959$ \\
\hline
\end{tabular}

$*=$ Significantly $(\mathrm{p} \leq 0.05)$ different from their respective values 
Table.5 Summary of interspecies comparison of cattle and buffalo milk

\begin{tabular}{|c|c|c|c|c|c|c|}
\hline \multirow[t]{2}{*}{ Residue } & \multicolumn{3}{|c|}{ Cattle $(n=310)$} & \multicolumn{3}{|c|}{ Buffalo ( $n=490$ ) } \\
\hline & $\begin{array}{c}\text { No. of } \\
\text { samples } \\
\text { having } \\
\text { detectable } \\
\text { level }\end{array}$ & $\begin{array}{c}\text { No. of } \\
\text { samples } \\
\text { having non } \\
\text { detectable } \\
\text { level }\end{array}$ & $\begin{array}{l}\text { Above } \\
\text { MRL }\end{array}$ & $\begin{array}{c}\text { No. of } \\
\text { samples } \\
\text { having } \\
\text { detectable } \\
\text { level }\end{array}$ & $\begin{array}{c}\text { No. of } \\
\text { samples } \\
\text { having non } \\
\text { detectable } \\
\text { level }\end{array}$ & $\begin{array}{l}\text { Above } \\
\text { MRL }\end{array}$ \\
\hline Cd & 246 & 64 & 0 & 231 & 169 & 0 \\
\hline $\mathbf{P b}$ & 193 & 117 & 0 & 205 & 195 & 0 \\
\hline $\mathrm{Cu}$ & 198 & 152 & 0 & 141 & 259 & 0 \\
\hline
\end{tabular}

MRLs of $\mathrm{Cd}, \mathrm{Pb}$ and $\mathrm{Cu}$ are taken as 1.5, 2.5 and $30 \mathrm{mg} / \mathrm{L}$, respectively as per FSSAI (2011)

The similar higher range of $\mathrm{Pb}$ concentration $(2.082-2.024 \mathrm{mg} / \mathrm{L})$ was reported by Iftikhar et al., (2014) in the Peshawar area of Pakistan in cattle and buffalo milk. The maximum concentration of $\mathrm{Pb}$ in buffalo milk in present study observed to be higher than those reported by Nirgude and Bhagure (2015) for buffalo milk in India and Arafa et al., (2014) for cattle and buffalo in Egypt. The maximum concentration of $\mathrm{Pb}$ in cow milk was also found to be higher in the present study than those $(0.052 \mathrm{mg} / \mathrm{L})$ reported by Dhanalakshmi and Gawdaman (2013) in Tamilnadu. The concentrations range of $\mathrm{Pb}$ in present study was observed to be lower than those reported in cows in Iran (Nejatolahi et al., 2014) and, cattle and buffalo in Nigeria (Farid and Baloch, 2012). Higher concentration of $\mathrm{Pb}$ in milk was found due to fodder contamination, climatic factors such as wind, use of agrochemicals and very importantly, high level of contaminants in drinking water. Furthermore, dairy animals graze along rail lines and roadsides contribute the same. Many times, the dairy farms or animal stable are located in close approximation to busy traffic roads and lead which is a fuel additive is emitted from the automobile exhaust to contaminate such environment.

In the present study, the concentration range of $\mathrm{Cd}$ in cattle and buffalo milk were observed to 0.001 to 0.080 and 0.001 to 0.088 $\mathrm{mg} / \mathrm{L}$ with mean concentrations of 0.030 and $0.033 \mathrm{mg} / \mathrm{L}$, respectively. The observed concentration of $\mathrm{Cd}$ was found to be lower than those reported in milk of cattle as 1.532 $\pm 0.124 \mathrm{mg} / \mathrm{L}$ by Alani and Al-Azzawi (2015) in raw milk collected from Iraq; $4.16 \mathrm{mg} / \mathrm{L}$ by Lyocks et al., (2013) in Kaduna Metro area, Nigeria; $0.416 \mathrm{mg} / \mathrm{L}$ by Salah et al., (2012) in Egypt and $0.532 \mathrm{mg} / \mathrm{L}$ by Leonidis et al., (2010) in Thessaloniki, capital of Greek Macedonia. According to a study report by Caggiano et al., (2005) from Romania, concentration of $\mathrm{Cd}$ in cattle milk samples ranged from 1.000 to $5.000 \mathrm{ppm}$ and lower concentration range of $\mathrm{Cd}$ in cattle and buffalo milk were observed in the present study.

Abnormal concentrations of $\mathrm{Cu}$ in tissue and blood causes Wilson disease, and acute exposure to $\mathrm{Cu}$ cause vomiting, hypertension, and cardiovascular collapse (Ogabiela et al., 2011), and the occurrence of $\mathrm{Cu}$ in milk is likely to be influenced by the environment (Qin et al., 2009). The value of $\mathrm{Cu}$ concentration ranged from 0.001 to $2.37 \mathrm{mg} / \mathrm{L}$ and from 0.001 to $8.959 \mathrm{mg} / \mathrm{L}$ with mean concentrations of 0.097 and $0.168 \mathrm{mg} / \mathrm{L}$, respectively in cattle and buffalo milk. The concentration of $\mathrm{Cu}$ was lower in cattle milk as compared to buffalo milk. Higher concentrations of $\mathrm{Cu}$ in the milk of cow were observed by Alani and Al-Azzawi (2015); 
Gebrelibanos et al., (2015); Malhat et al., (2012); Kodrik et al., (2011); EI-Sayed et al., (2011) and AL-Wabel (2008). Similarly, higher concentration of $\mathrm{Cu}$ in the milk of both cattle and buffalo (1.692 mg/L) was also reported by Arafa et al., (2014).

The overall summary reflected that no samples collected from any area from any species showed the presence of metals $(\mathrm{Cd}$, $\mathrm{Pb}$ and $\mathrm{Cu}$ ) above recommended MRLs as per FSSAI and the study demonstrated nonsignificant variation in the levels of all metals under investigation in cattle and buffalo milk.

\section{Acknowledgement}

Authors are very much thankful to the ICAR for providing financial assistance to carry out research work under the ICAR sponsored outreach programme on Monitoring of drug residues and environmental pollutants.

\section{References}

Abdulkhaliq, A., K. M. Swaileh, R. M. Hussein and Matani, M. 2012. Levels of metals $(\mathrm{Cd}, \mathrm{Pb}, \mathrm{Cu}$ and $\mathrm{Fe})$ in cow's milk, dairy products and hen's eggs from the West Bank, Palestine. Int. Food Res. J. 19(3): 1089-1094.

Ahmad, N., M. Rahimb and Haris, M. 2011. Toxocological impact assessement of heavy metals in human blood and milk samples collected in district Shangla, Pakistan. Sci. Int. (Lahore). 26(1): 223226.

Alani, M. S., and Al-Azzawi, M. N. 2015. Assessment of lead, cadmium and copper concentrations in raw milk collected from different location in Iraq. Iraqi J. Sci. 56(1B): 350-355.

AL-Wabel, N. A., 2008. Mineral contents of milk of cattle, camels, goats and sheep in the central regions of Soudi Arabia. Asian J. Biochem. 5(6): 373-375.
Arafa, M. S., A. M. Walaa and Hassan, N. Y. 2014. Heavy metals and trace elements levels in milk and milk products. $J$. Food. Measure. Charact. 8: 381-388.

Aslam, B., I. Javed, F. H. Khan and Rahman, Z. U. 2011. Uptake of heavy metal residues from sewerage sludge in the milk of goat and cattle during summer season. Pak. Vet. J. 31: 75-77.

Bernard, A., 2008. Cadmium and its adverse effects on human health. Ind. J. Med. Res. 128: 557-564.

Birghila, S., S. Dobrinas, G. Stanciu and Soceanu, A. 2008. Determination of major and minor elements in milk through ICP-AES. Environ. Eng. Manag. J. 7(6): 805-808.

Bushra, I., A. Saatea, S. Samina and Riaz, K. 2014. Assessment of toxic metals in dairy milk and animal feed in Peshawar, Pakistan. British Biotech. J. 4(8): 883893.

Caggiano, R., S. Sabia, M. D’Emilio, M. Macchiato, A. Anastasio, M. Ragosta and Paino, S. 2005. Metal levels in fodder, milk, dairy products and tissues sampled in ovine farms of Southern Italy. Environ. Res. 99: 48-57.

Dhanalakshmi, B., and Gawdaman, G. 2013. Determination of heavy metals in goat milk through ICP OES. Asian J. Dairy Food Res. 32: 186-190.

EI-Sayed, E. M., A. M. Hamed, S. M. Badran and Mostafa, A. A. 2011. A survey of selected essential and toxic metals in milk in different regions of Egypt using ICP-AES. Int. J. Dairy Sci. 6(2): 158164.

Farid, S., and Baloch, M. K. 2012. Heavy metal ions in milk samples collected from animals feed with city effluent irrigated fodder. Greener J. Phys. Sci. 2(2): 36-43.

FSSAI, 2011. Ministry of Health and Family Welfare. (Food Safety and Standards Authority of India). 
Gebrelibanos, A., T. Kebede and Belay, K. 2015. Quantitative determination of the level of selected heavy metals in the cow's milk from dairy farm of the Haramaya University, Eastern Ethiopia. Int. J. Chem. Nat. Sci. 3(1): 240-248.

Gonzalez-Montana, J. R., E. Senis, A. Gutierrez and Prieto, F. 2012. Cadmium and lead in bovine milk in the mining area of the Caudal River (Spain). Environ. Monit. Assess. 184: 40294034.

Iftikhar, B., S. Arif, S. Siddiqui and Khattak, R. 2014. Assessment of toxic metals in dairy milk and animal feed in Peshawar, Pakistan. British Biotech J. 4(8): 883893.

Javed, I., I. Jan, F. Muhammad, Z. Rahman, M. Z. Khan, B. Aslam and Sultan, J. I. 2009. Heavy metal residues in the milk of cattle and goats during winter season. Bull. Environ. Contam. Toxicol. 2: 616620.

Kodrik, L., L. Wagner, K. Imre, K. F. Polyak, F. Besenyei and Husventh, F. 2011. The effect of highway traffic on heavy metal content of cow milk. Hung. J. Ind. Chem. Veszprem. 39: 15-19.

Leonidis, A., V. Crivineanu, G. V. Goran and Codreanu, M. D. 2010. The level of heavy metals in milk from cattle farmed near polluting industries in the province of Thessaloniki. Lucrari Stiintifice Medicina Veterinara. 43(2): 153-158.

Licata, P., D. Trombetta, M. Cristani, F. Giofre, D. Martino, M. Calo and Naccari, F. 2004. Levels of toxic and essential metals in samples of bovine milk from various dairy farms in Calabria, Italy. Environ. Int. 30: 1-6.

Lyocks, S. W. J., R. G. Ayo, J. Tanimu and Olajide, J. O. 2013. Mineral elements content in raw milk of grazing cattle in Kaduna metropolis and environs. Nigerian J. Agri. Food Environ. 9(1): 22-27.
Malhat, F., M. Hagag, A. Saber and Fayz, A. 2012. Contamination of cow's milk by heavy metal in Egypt. Bull. Environ. Contam. Toxicol. 88: 611-613.

Morrison, J. N., and Quarterman, J. 1987. The relation between iron status and lead absorption in rats. Biol. Trace Element Res. 14: 115-126.

Nazir, R., M. Khan, H. Rehman, M. Masab, A. Khan, M. Rehman, A. Khaliq, I. Parveen and Shehnaz, F. 2015. Comparative study of heavy metals $(\mathrm{Ni}$, $\mathrm{Cu}, \mathrm{Fe}$ and $\mathrm{Cr}$ ) in the milk of cattle and humans collected from Khyber Pakhtunkhwa, Pakistan. Global Veterinaria. 14(5): 761-767.

Nejatolahi, M., F. Mehrjo, A. Sheykhil and Bineshpor, M. 2014. Lead concentrations in raw cows' milk from Fars Province of Iran. Am. J. Food Nutr. 2(5): 92-94.

Nirgude, N. T., and Bhagure, G. R. 2015. Heavy metals and mineral elements in milk of buffaloes at Boisar-Tarapur industrial area, Palghar District, Maharashtra, India. Am. Int. J. Contemp. Sci. Res. 2(1): 70-78.

Ogabiela, E. E., U. U. Udiba, O. B. Adesina, C. Hammuel, F. A. Ade-Ajayi, G. G. Yebpella, U. J. Mmereole and Abdullahi, M. 2011. Assessment of metal levels in fresh milk from cows grazed around Challawa Industrial Estate of Kano, Nigeria. J. Basic Appl. Sci. Res. 1(7): 533-538.

Patel, H. B., R. D. Singh, R. R. Desai, S. K. Mody and Gondaliya, S. B. (2017). Determination of lead and cadmium level in milk of dairy animals in Mehsana district of Gujarat using ICPAES. Bull. Environ. Pharmacol. Life Sci. 6(6): 54-58.

Pitot, C. H., and Dragan, P. Y. 1996. Chemical carcinogenesis. In: Casarett and doull's toxicology. $5^{\text {th }} \mathrm{Ed}$, 
International Edition, McGraw Hill, New York, pp. 201-260.

Poti, P., F. Pajor, A. Bodnar and Bardos, L. 2012. Accumulation of some heavy metals $(\mathrm{Pb}, \mathrm{Cd}$ and $\mathrm{Cr})$ in milk of grazing sheep in North-East Hungary. $J$. Microbiol. Biotech. Food Sci. 2(1): 389394.

Qin, L. Q., X. P. Wang, W. Li, X. Tong and Tong, W. J. 2009. The minerals and heavy metals in cow's milk from China and Japan. J. Health Sci. 55(2): 300305.

Salah, F. A., I. A. Esmat and Rania, M. K. M. 2012. Prevalence of some trace and toxic elements in raw and sterilized cow's milk. J Ani. Sci. 8(9): 753-761.

Tona, G. O., V. O. Adetunji, S. A. Ameen and Ibikunle, A. O. 2013. Evaluation of lead and cadmium heavy metal residues in milk and milk products sold in Ogbomoso, Southwestern Nigeria. Pak. J. Nutr. 12: 168-171.

Zheng N., Q. Wang, X. Zhang, D. Zheng, Z. Zhang and Zhang, S. 2007. Population health risk due to dietary intake of heavy metals in the industrial area of Huludao city, China. Sci. Total Environ. 387: $96-104$.

\section{How to cite this article:}

Rashmika R. Desai, Hitesh B. Patel, Ratn Deep Singh, Vaidehi N. Sarvaiya, Mahesh M. Pawar and Shailesh K. Mody. 2018. Heavy Metal Concentrations with Regard to Inter-Species Variation in Cattle and Buffalo Milk Collected from Different Areas of North Gujarat. Int.J.Curr.Microbiol.App.Sci. 7(08): 1774-1782. doi: https://doi.org/10.20546/ijcmas.2018.708.203 